\title{
DEMOGRAPHIC AND ECONOMIC FACTORS INFLUENCING THE REAL-ESTATE MARKET IN ROMANIA
}

\author{
Remus Dorel ROȘCA, Sebastian ȘIPOȘ-GUG \\ University of Oradea, Faculty of Economics, Oradea, Romania \\ roscaremus10@gmail.com \\ sebastian.siposgug@gmail.com
}

\begin{abstract}
Forecasting the evolution of the residential real-estate market on the longer term is a daunting task that we aim to improve by looking into the relationship between home prices and real-estate transactions and several demographic indicators: number of marriages, divorces, birth-rates and deathrates, as well as several other factors, including income, employment and interestrates. By looking at the monthly data for Romania between April 2009 and September 2016, and using a path analysis approach, we tested our proposed model and, after making several adjustments to it in order to increase its power, we found a way to relate the demographic indicators, prices and transactions that could provide assistance both in explaining the dynamics of the real-estate market and aid in making forecasts that related to these indicators. Our main results point to a negative relationship between prices and transactions, which is in line with our expectations and current economic theory. We also find that income has a positive relationship with the number of transactions and a negative one with home prices. However, the latter can be fully explained by a mediation effect though the former, and thus there is a strong possibility that changes in income have an indirect effect on prices, by their effect on transactions. In terms of demographics indicators, divorces are positively related to prices, births are positively related with transactions, while marriages have an inverse relationship with the number of transactions and we failed to find any indicators that deaths have a strong relationship to either prices or transactions. These effects are relatively smaller than those of income or employment, but nonetheless on the longer term they add up and, after all, demographic trends change slower. We conclude that marriages, divorces and births are related to changes in home prices and number of transactions in the Romanian real-estate market and that their long-term trends could be important in assessing the future of this market.
\end{abstract}

Keywords: home prices; real-estate transactions; demographics;

JEL Classification: R31; R21; J11.

\section{Introduction}

The real estate market has a relatively big impact on the lives of people, with prices and transaction activity being closely tied to the living conditions one can afford, where we live and, often, what work opportunities are available for adults and educational options for children. Not to mention that, for a large portion of the population, their house will be the single most valuable asset they own and will be the biggest contributor to their net worth. For those with above average income, a second house or apartment to lease might be a big part of their retirement plan. 
There are also cultural aspects to consider, as the home ownership rate in Romania in 2019 was $95.8 \%$, the biggest in the EU, which averages just $69.8 \%$ (Eurostat, 2021a), thus pointing towards the high desire of Romanians to own a home. Thus, when looking at the overall demographic changes that Romania is currently going through, one must wonder how all this will change in the future.

Table 1. Evolution of births, marriage and divorce between 1990 and 2019

\begin{tabular}{|l|l|l|l|l|}
\hline Year & $\mathbf{1 9 9 0}$ & $\mathbf{1 9 9 9}$ & $\mathbf{2 0 0 9}$ & $\mathbf{2 0 1 9}$ \\
\hline Mean age of women at birth & 22,3 & 23,5 & 25,5 & 27,6 \\
\hline Fertility rate per 1000 inhabitants & 13,6 & 10,3 & 9,9 & 9,2 \\
\hline Mortality rate per 1000 inhabitants & 10,6 & 11,6 & 11,4 & 11,7 \\
\hline Marriage rate per 1000 inhabitants & 8,3 & 6,1 & 6 & 5,8 \\
\hline Median age at first marriage & 25 & 26,5 & 29,1 & 31,6 \\
\hline Divorce rate per 1000 inhabitants & 1,42 & 1,51 & 1,44 & 1,36 \\
\hline
\end{tabular}

Source: National Statistics Institute

We are noticing demographic decline (from 19.281 million in 2020 to an forecasted 15.5 million by 2050, source: Eurostat, 2021b), with lower birth rates, declining rates of marriage, higher age at birth and marriage (source: National Statistics Institute), and all these might have a negative impact on the residential real estate market on the longer term. On the other hand, average income has been rising faster than inflation, and interest rates are at a historical low. This might sound like good news for the market at the moment, but on the longer term the interaction of all these variables is complex, and predicting how the market might look like in few decades might be dependent on all of them.

The impact of demographic factors on the real estate market has been investigated across the globe, and results seem to be different between countries. Developing economies often find a positive relationship between demography and real estate indicators, like in Kenya (Karoki, 2013) or Ghana (Obeng-Odoom, 2010), while some developed nations expect the impact to be a negative one and are preparing mitigation measures to prevent market decline, like in Germany (Berndgen-Kaiser et al., 2014)

When it comes to the Romanian market, several studies found relationships between demographics and home prices (Anghel \& Hristea, 2013; Șipoș, 2018) or the number of transactions (Enăchescu \& Bănică, 2019). Sorcaru (2020) also points towards internal migration of the elderly towards rural areas as a factor of urban depopulation, which would also lead to increased number of transactions. Looking at economic indicators influencing the real-estate market, Anica-Popa (2013) and Simionescu (2014) conclude that increases in interest rates have a negative impact on it. In addition to interest rates, other measures by the National Bank, like loan-to-value restrictions, seem to be more reactionary, rather than causal in nature, when it comes to their impact on the market (Neagu, Tatarici \& Mihai, 2015). Popescu \& Ciora (2015) also suggest that GDP, unemployment, interest rates, income and government programs can all influence the real-estate market. The relationship is not clear-cut however, since Enăchescu \& Bănică (2019) didn't find a strong indicator that GDP, income and transactions are related. The current paper aims to continue their work, and to explore the relationship between all these potential indicators and the changes in home prices and number 
of transactions, in order to improve both our theoretical understanding of the markets and our ability to effectively provide long term forecasts for it.

\section{Proposed model}

Based on our literature review and personal experience, we created a theoretical model of housing prices and real estate transaction, based on social, economic and demographic variables. The model is succinctly presented in the neighboring graph, with arrows indicating directional or bi-directional relationships. Full lines symbolize direct relationships and dotted lines reverse relationships.

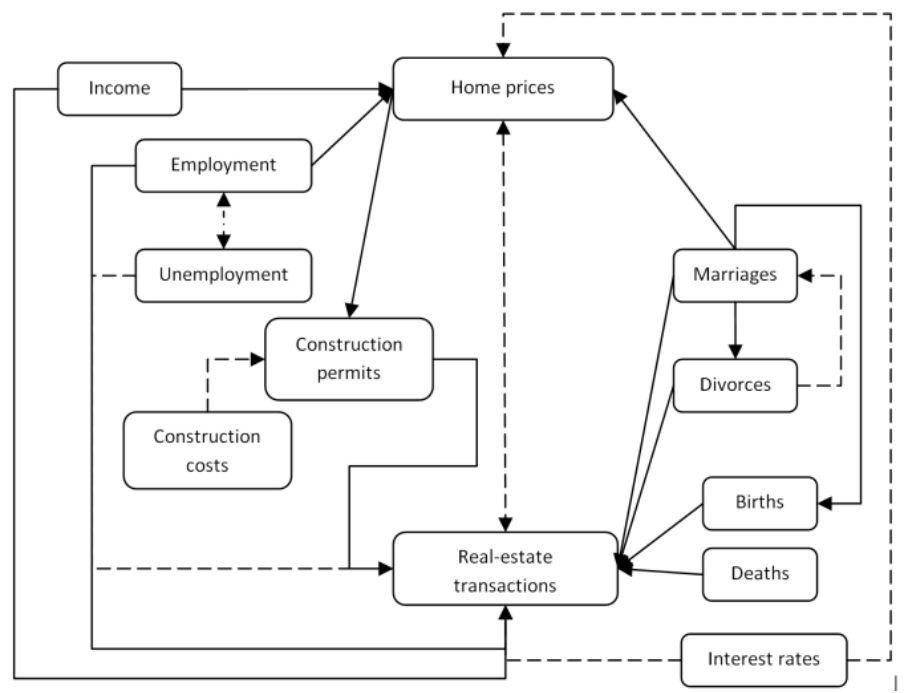

Figure 1: The proposed model of home prices and real-estate transactions

Testing a model of this complexity can be difficult, requiring time series long enough to provide a reasonable statistical power. For this purpose we chose the finest-grained time series available, that of monthly data and we used this as a main criterion for indicator selection. In order to control some of the downsides of monthly data, we further looked at seasonality and potential breaks in the time series for each indicator, that might influence the testing of our model.

\section{Indicators}

\subsection{Real estate transactions}

The data regarding real estate transactions was collected from the National Agency for Cadastre and Land Registration (ANCPI), and was available starting with January 2009. A potential issue with this data source is that it tracks total transactions, not only residential ones. However, since 2017, they do provide a break-down of the series,

In order to see if there are any structural changes in the time series, as it might have been collected or reported differently over the years, we used the breakpoints function of the strucchange $R$ package, version 1.5-2. The test pointed to three potential breakpoints, April 2012, February 2015 and September 2016. The 2012 
and 2015 points might point to market changes (by 2012 the market had stabilized after the 2008 crisis and starting with 2015 it returned to a growth trend). However, since ANCPI also changed its data reporting structure in 2016, this will have to be taken into account in the further analyses.

Seasonality is also of concern, especially when dealing with construction related data. To test for seasonality we used the WO test, from the seastests R package, version 0.14.2, which rejected the lack of a seasonal component. In order to decompose the time series, we used the STL function from the stats $\mathrm{R}$ package, version 3.6.3. After eliminating the seasonal component, the WO test failed to reject the lack of a seasonal component $(p=0.747)$, thus we concluded that our real estate transaction time series has a 12 - month (additive) period.

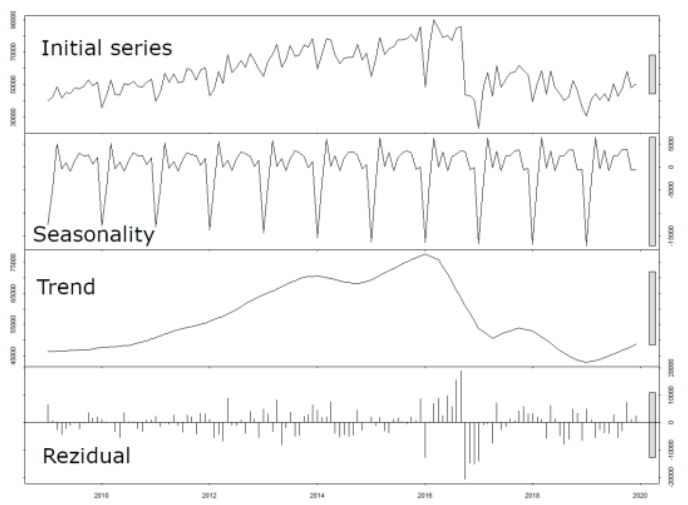

Figure 2. Seasonal decomposition of the number of real-estate transactions Source: Author's calculations based on data from the National Agency for Cadastre and Land Registration

Another concern is that of stationarity. In order verify this, we used the $A D F$ (Augmented Dickey-Fuller) and KPSS (Kwiatkowski-Phillips-Schmidt-Shin) test, of the $\mathrm{R}$ package tseries, version $0.10-47$. This approach is often recommended, since each of the alone can be prone to Type I errors (Charemza and Syczewska, 1998, Kębłowski and Welfe, 2004). Both tests pointed to a lack of stationarity of the initial time series, but not so after a level 1 differentiation and so we concluded that a single differentiation can make the time series stationary.

\subsection{Home prices}

Data regarding home prices is available from multiple sources. The National Statistics Institute (INS) publishes a quarterly index, that is also the source for the Eurostat database. This is however a poor choice for our study, since it's availability is limited in time, and the reporting period is a quarterly one. Instead, we used as a proxy for home prices the IMO index, published by the imobiliare.ro website. This is the average asking price in Euro per square meter of an apartment on the website and is has a monthly reporting frequency. While there can be a difference between asking prices and real prices and the website is only a sample of the entire market, the fact that the data is available since March 2008 and the reporting frequency makes it a better suited choice for our study. Moreover, we compared the trends of the two indices (by converting both to annual rate of 
change) and they strongly overlap, with an $r=0.93$, thus it would seem that they both change very similarly from year to year.

We performed the same tests regarding continuity, seasonality and stationarity as we did previously for home transactions. We identified four potential breakpoints, that correspond to changes in the trend of the indicator: an accelerated drop in prices starting with July 2010 , followed by stabilization after June 2012, fast growth starting with January 2016 and a slower growth from August 2017 onwards.

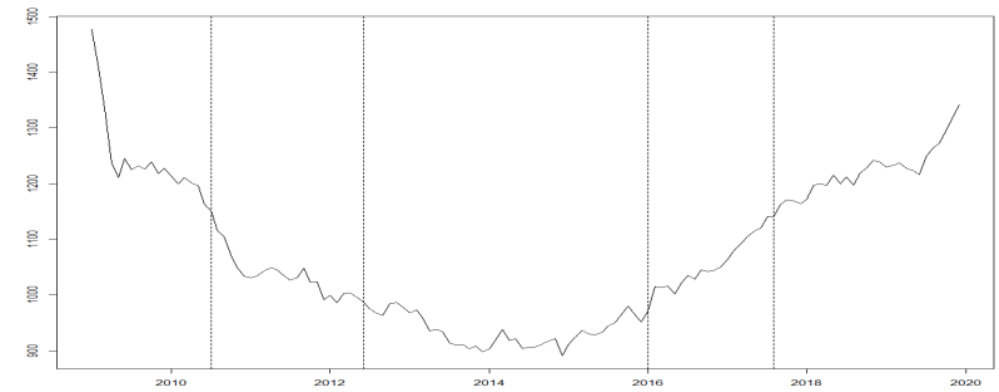

Figure 3. Breakpoint analysis of home prices

Source: Author's calculation based on data from imobiliare.ro

The WO test failed to reject the lack of a seasonal component $(p 1=0.118, p 2=$ 0.47 ), and thus we continued our work on the assumption that our home price indicator is not subject to seasonal variation. This would be in contrast with studies on other markets, that did find seasonality in the variation of home prices in USA (Miller et al., 2013), UK (Kajuh \& Schmidt, 2016), or Poland (Trojanek, 2013)

Regarding stationarity, both the ADF and KPSS tests pointed to a high chance of the time series not being stationary $(p=0.934$ and $p<0.01$, respectively), but this changed after an order 1 differentiation both tests $(p<0.01$ and $p>0.1$, respectively). Thus, where stationarity is important, we recommend using the first order differential of this time series.

\subsection{Demographic indicators}

We looked at several demographic indicators, all reported publicly by the National Statistics Institute: births, deaths, number of marriages and number of divorces. We collected the monthly data from the January 2009 - December 2019 interval, as to match the available time frame for the other indicators.

All four indicators showed signs of seasonality, with the WO test failing to reject this hypothesis, and we found that they have an additive seasonal component.

Regarding stationarity, with the exception of birth rates, the other time series didn't raise any concerns, with both the ADF and KPSS tests pointing to a very low chance that they are not stationary. In the case of birth rates, a declining trend was indentified and the series was found to be stationary around this trend.

\subsection{Economic indicators}

We also wanted to include in our model several key economic indicators that have been traditionally related to the real-estate market, namely income, employment, interest rates. We also included the number of building permits issued and construction costs, as potential factors in our model. 
The majority of this data was collected from the INS, using the following data series:

- "Monthly average net earnings in the economy" in the case of income

- "Number of employees at the end of the month" for employment

- "Registered unemployed at the end of the month"

- "Building permits by type of construction"

- "Construction cost indices - base year 2015" for construction costs

Our source for interest rates for housing loans was the National Bank of Romania, and we used as an indicator the average interest rate for loans as a weighted mean of interest rates for various currencies and using volume of loans as weights. We performed the same tests for stationarity and seasonality as previously, and there were only two potential issues: income showed signs of seasonality (WO test $\mathrm{p}<0.001$ ) and unemployment requires an first order differentiation to be stationary.

\section{Testing the model}

In order to test the model using the previously mentioned data sources, we resorted to a path analysis, conducted by applying the sem function from the lavaan $\mathrm{R}$ package, version 0.6-7. Time series were shortened to the interval April 2009 - September 2016 in order to minimize the impact of breaks in data.

The function call used the following model parameters:

\{ Prices $\sim$ Income + Marriages + Divorces + Births + Deaths + Interest rates + Persons Employed + Persons Unemployed + Construction Permits

Transactions $\sim$ Income + Marriages + Divorces + Births + Deaths + Interest rates + Persons Employed + Persons Unemployed + Construction Permits

Births Income + Marriages

Persons Employed Persons Unemployed \}

The initial model failed our chi-squared fit test $(p<0.001)$, thus we looked into what might cause this result. Since our sample size was relatively low (85 time points), the chi-squared test would be a reasonable measure (Kenny, 2020), however we would normally want at least 200 cases for the SEM model to achieve sufficient statistical power. Since collecting more data is not practical in this case, we decided to strip down the model and reduce its complexity. The final version of our model had a adequate chi-squared fit $(p=0.771)$ and all coefficients were significantly different from $0(p<0.05)$.

The revised model had the following parameters:

\{ Prices Income + Divorces + Persons Employed + Persons Unemployed

Transactions $\sim$ Income + Marriages + Births + Interest rates + Persons Unemployed + Construction Permits \}

In order to simplify the interpretation of our results, we resorted to a graphical representation of the data, using green arrows to point to a direct relation and red arrows to point to indirect relations. Arrow thickness is proportional to the size of the relationship. We also removed auto-correlation terms from this representation, as to keep the image as simple as possible. We decided to leave in significant correlations between other variables (outside of our model) and they are marked with a dotted line, in this case not proportional to effect sizes. 


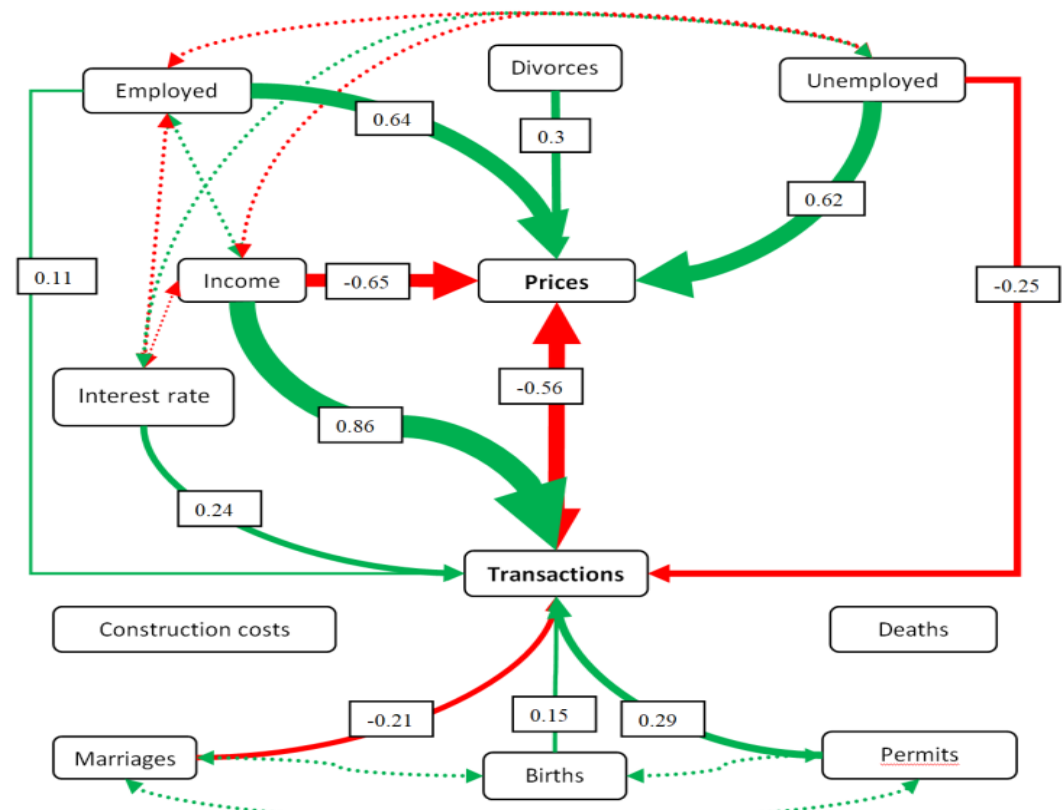

Figure 4. Tree graph of the revised model Source: Author's calculations

\section{Results}

Our model shows that the main factors helping to predict apartment prices are the number of employed and unemployed persons, divorces, income and the number of real estate transactions, with the latter two having a negative relation with prices. Some of these results are in line with our expectation. In fact, the relationship between price and number of transactions is but a confirmation of the long established relationship between supply and price, in general.

At a first glance, we were taken aback by the negative relation between income and prices, since common sense would have predicted that an increase in average income would translate to an increase in average home prices. Thus, we decided to look a bit further into this relationship. We looked at transactions as a potential mediator between income and prices. We used the mediate function of the $\mathrm{R}$ package mediation, version 4.5.0, and the results were in favor of our hypothesis. That is, they showed that the number of transactions completely mediates the relationship between income and apartment prices. We can conclude, then, that an increase in income is indeed related with a decrease in apartment prices, potentially due to the indirect effects of increased real estate transactions. This relationship will require further study, as it has not been the focus of our paper.

Employment/unemployment and their relation to prices also seems rather complex, with them having a reversed correlation to each other, but both having a positive relation to apartment prices. Unfortunately, we could not look at more macro economical indicators related to employment, since they are reported quarterly or yearly, and would not have fitted our study's design. Most likely unemployment and prices rise together in periods of economic unease, when interest rates also 
increase (we also found a positive relationship between unemployment and interest rates). An increase in unemployment might mean fewer lower income persons that can buy apartments, and thus fewer transactions. The remaining transactions would be those involving homes that are more expensive and thus average prices go up. Anecdotally, we can see this in the current (Q1 2021) real estate market. Since there are so few investment opportunities for those with excess income, many choose to invest in apartments, pushing the prices upwards, despite an overall less optimistic forecast regarding employment.

The demographic factors were related to transactions, with marriages having a negative impact on them, while births having a positive one. While we expected births to lead to more transactions, since an expanding family would often require more room and/or parents would change their housing preferences to better accommodate children (having a yard, proximity to schools, etc.), the negative relation to marriages was in opposition with that proposed by our model. We cannot eliminate the probability that this is an artifact of both variables being nonstationary, there might actually be an economic explanation: many young couples move in to a home one of them already owns, and then buy a new home at a later date, perhaps once a child is born. Supporting this hypothesis is the fact that the median age of marriage is rising, and with the high rates of home ownerships in Romania there are good odds that one, or both partners, already own a home at 31 years (the median age of first marriage in 2019). We also found that divorces have a positive relationship with prices, while we initially expected them to be related to transactions (since a divorce would likely mean one of the partners moves out). For now, our best explanation is that separation and divorce might occur at different moments in time, and a couple would file for divorce when they try to divide their assets, and this would take place when they get a good price for them. This relationship would be interesting to investigate in more detail, as there could be other intervening factors that we missed.

\section{Conclusions}

We proposed a model of demographic and economic factors influencing the real estate market in Romania. While our proposed model proved to be too complex to test with adequate statistical power using the data at hand, we have revised and simplified it as much as possibly, without losing it's core ideas.

We found that income was the strongest factor related to both asking prices for homes and the number of total real estate transactions. Furthermore, we found that its impact on prices can be fully mediated by its relation to transactions. Thus, measures aimed at increasing wages could be used to, paradoxically, lower home prices, via their strong impact on the number of transactions.

At the same time, employment and unemployment both have a positive impact on prices, but a different impact on transactions, with employment leading to more transactions, while unemployment to fewer. This points to a complex relation between the four indicators, and shows that increases in employment can have a positive impact on the real-estate market, while unemployment leads to fewer, but more valuable on average, transactions.

Not the least, demographic indicators also play a role, with divorces positively tied to home prices, while births seem to lead to more transactions. Marriages are, 
contrary to our expectations, a negative factor of real-estate transactions, despite their positive relationships with births and home permits. While their impact is relatively smaller than that of the economic indicators we looked it, nonetheless forecasters and policy makers alike should try to factor them in their models, as they can provide valuable insights of the longer term trends.

\section{References}

1. Anica-Popa, A, (2013) Piaţa imobiliară şi evoluţia dobânzii, Economie teoretică şi aplicată, XX, Supliment, 53-64.

2. Anghel, I., \& Hristea, A. M. (2013). Evoluţia demografică, dinamica fondului de locuinţe în România și evoluția prețurilor proprietăților imobiliare din România. Economie teoretică şi aplicată, XX, 5-12.

3. Berndgen-Kaiser, A., Bläser, K., Fox-Kämper, R., Siedentop, S., \& Zakrzewski, P. (2014). Demography-driven suburban decline? At the crossroads: mature singlefamily housing estates in Germany. Journal of Urbanism, 7(3), 286-306.

4. Charemza, W., \& Syczewska, E. (1998). Joint application of the Dickey-Fuller and KPSS tests. Economics Letters, 61(1), 17-21.

5. Enachescu, P. C., \& Bănică, C. (2019). Analysis Of The Real Estate Market In Romania From The Point Of View Of The Number Of Transactions During 20092018. Scientific Bulletin-Economic Sciences, 39-46.

6. Eurostat (2021a), Distribution of population by tenure status, type of household and income group - EU-SILC survey [Online] https://ec.europa.eu/eurostat/databrowser/view/ilc_Ivho02/default/table?lang=en [31.03.2021]

7. Eurostat (2021b), Population on 1st January by age, sex and type of projection [Online]https://appsso.eurostat.ec.europa.eu/nui/show.do?dataset=proj_19np\&lang $=$ en [31.03.2021]

8. Imobiliare ro (2021) Indicele

https://www.imobiliare.ro/indicele-imobiliare-ro [31.03.2021]

9. Kajuth, Florian and Schmidt, Tobias, (2011). Seasonality in House Prices Bundesbank Series 1 Discussion Paper No. 2011,08.

10. Karoki, R. W. (2013). Determinants of residential real estate prices in Kenya (Doctoral dissertation, University of Nairobi).

11. Kębłowski, P., \& Welfe, A. (2004). The ADF-KPSS test of the joint confirmation hypothesis of unit. Economics Letters, 85(2), , 257-263.

12.Kenny, D.A. (2020) Measuring Model Fit [Online] http://www.davidakenny.net/cm/fit.htm [01.09.2020]

13. Miller, Norman G., Vivek Sah, Michael Sklarz, and Stefan Pampulov. (2013). Is There Seasonality in Home Prices_Evidence from CBSAs. Journal of Housing Research 22, no. 1: 1-16.

14. Neagu, F., Tatarici, L., \& Mihai, I. (2015), Implementing Loan-to-Value and Debt Service-To-Income measures: A decade of Romanian experience. Munich Personal RePEc Archive: https://mpra.ub.uni-muenchen.de/65988/

15. Obeng-Odoom, F. (2010). Urban real estate in Ghana: A study of housingrelated remittances from Australia. Housing Studies, 25(3), 357-373. https://doi.org/10.1080/02673031003711568

16. Popescu, D. D., \& Ciora, C., (2015) Determinants of the real estate market: the Romanian case, "Theoretical and Applied Economics", XXII, 21-34. 
17. Simionescu, M., (2014) Un model quantilic autoregresiv cu lag distribuit pentru prețul locuințelor în România, Studii Şi Cercetări De Calcul Economic Şi Cibernetică Economică

18. Sorcaru, I. A. (2020). Urban Depopulation in Romania. Annals of "Dunarea de Jos" University of Galati, 39-48.

19. Șipoș, C. (2018). Are correlated the real estate prices in Romanian cities to the living conditions offered? The Valuation Journal, 13(1), 5-21.

20. Trojanek, R. (2013). An attempt to identify the seasonality of housing prices in selected polish cities in 1996-2012. Real Estate Management and Valuation, 21(4), 96-109. 